\title{
低分子生体成分ミミック体の創出を基盤とする創薬化学研究
}

\author{
高畑廣紀
}

\section{Synthetic Medicinal Chemistry of the Biomolecular Components Mimics}

\author{
Hiroki Takahata \\ Faculty of Pharmaceutical Sciences, Tohoku Pharmaceutical University; Komatsushima 4-4-1, \\ Aoba-ku, Sendai 981-8558, Japan.
}

(Received February 13, 2013)

\begin{abstract}
We are studying the medicinal synthetic chemistry of biomolecular component mimics such as carbohydrates, nucleosides, amino acids, and peptides. In this review, the synthesis and biological activities of iminosugars as carbohydrate mimics are discussed. Glycosidases and glycosyltransferases are involved in a wide range of anabolic and catabolic process, including digestion, the lysosomal catabolism of glycoconjugates, glycoprotein biosynthesis. Hence, modifying or blocking these processes in vivo using inhibitors is a topic of great interest from the therapeutic point of view. Iminosugars are sugars in which the endocyclic oxygen is replaced by a basic nitrogen atom. They are regarded as transition state mimics in certain types of enzyme reactions. This makes the field of iminosugars as carbohydrate mimics an exciting area of research. We synthesized all of the stereoisomers of polyhydroxypiperidines such as fagomine, 1-deoxynojirimycine, and isofagomine. In addition, their both enantiomers, as substrates for a variety of glycosidases were evaluated. Secondly, the asymmetric synthesis of $\alpha-1-C$-alkyl-arabinoiminofuranoses was achieved by asymmetric allylic alkylation, RCM, and Negishi cross coupling as key reactions. Surprisingly, the L-forms showed a quite potent inhibitory activity toward rat intestinal maltase, while the activities of the D-forms were much weaker. Some of the prepared Lforms showed potent inhibitory activities towards intestinal maltase, with $\mathrm{IC}_{50}$ values comparable to those of commercial drugs such as acarbose, voglibose, and miglitol, which are used in the treatment of type 2 diabetes. Among them, the inhibitory activity towards intestinal sucrase of $\alpha-1-C$-L-butylarabinoiminofuranose was quite strong towards intestinal sucrase compared to the above commercial drugs.
\end{abstract}

Key words_— biomolecular component mimic; iminosugar; glucosidase inhibitor; $\alpha$-1- $C$-alkyl-arabinoiminofuranose; type 2 diabetes

\section{1. はじめに}

生体を構成する分子として重要なものには三大生 体高分子と呼ばれているタンパク質，核酸，糖質が あり, 生化学システムを構成する主役であり, 今日 でも生化学研究の重要な研究対象の源泉である. こ れらは低分子の単位物質が多数結合したもので，核 酸はヌクレオシド, タンパク質はアミノ酸, 糖質は 単糖類である。私たちは，生体内の様々な生命現象 を有機化学的（分子レベル）側面から解析し，それ らを基にした新たな生体関連物質の設計・合成とと もにそれらの機能性評価を行う研究を展開してい

The author declares no conflict of interest.

東北薬科大学（干981-8558 仙台市青葉区小松島 4 丁目 4-1)

e-mail: takahata@tohoku-pharm.ac.jp

本総説は, 平成 24 年度日本薬学会学術貢献賞の受賞を 記念して記述したものである.
る. 先に述べた低分子生体成分である, ヌクレオシ ド，アミノ酸 (ペプチド)，単糖のミミック体の創 製を機軸とする創薬化学研究を紹介する。本稿で は，糖ミミック体であるイミノ糖の探索研究中に得 られたわれわれのグループの知見を中心に述べる.

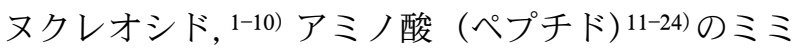
ック体に関する研究は文献を紹介するに留める.

2. イミノ糖の化学

ポストゲノム時代を迎え，今後はタンパク質の翻 訳後修飾の機能を解明することは極めて重要な課題 である。哺乳動物の場合，合成タンパク質の $90 \%$ 以上に糖鎖が付加しており，糖タンパク質や糖脂質 における糖鎖の機能を詳細に研究することが重要で ある.これら糖鎖の形成, 修飾に深く関与している グリコシダーゼ及びトランスフェラーゼを制御する 化合物を創出することができれば，それは単に細胞 

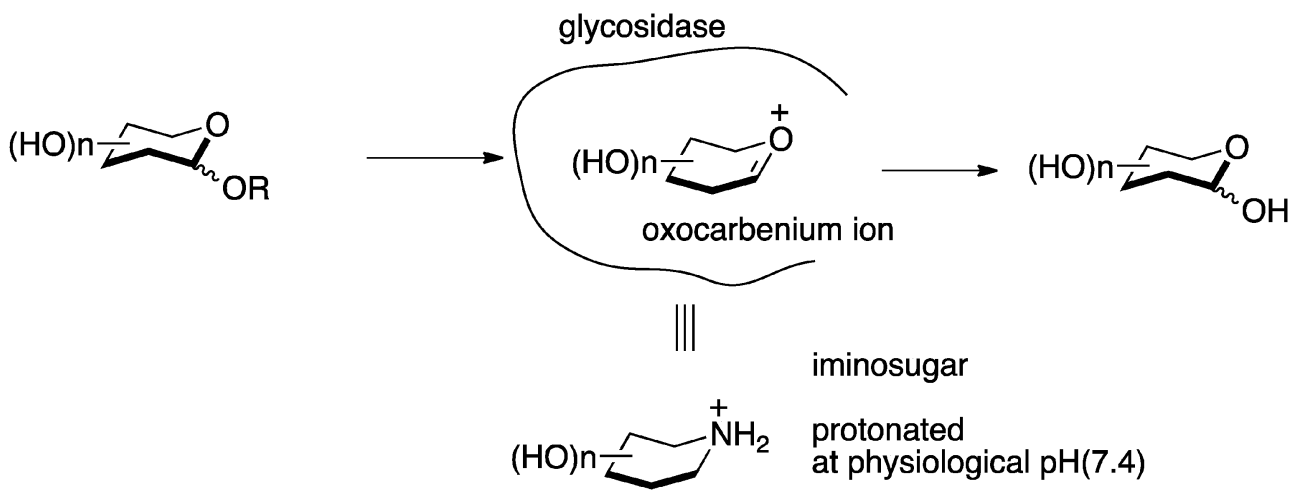

Scheme 1.

生物学的な観点に留まらず疾患の発症メカニズムの 解明や効果的疾患薬の開発といった応用研究を大幅 に進展させることになる。これらの候補群として近 年注目を浴びているのが酵素作用に対する潜在的遷 移状態（オキソカルベニウム様）アナローグである イミノ糖である (Scheme 1).

イミノ糖によって阻害される多様な酵素群は糖尿 病，ウイルス感染，リソソーム蓄積症，がん転移な ど非常に幅広い疾患に対する医薬品創出が期待され る極めて魅力的なものである。実際，臨床薬として 1996 年に II 型糖尿病薬として Glyset ${ }^{\mathrm{TM}}$ が, 2003 年に難病のリソソーム蓄積症であるゴーシェ病治療 薬とZavesca ${ }^{\mathrm{TM}}$ が上市されている，さらに，医薬品 候補として近年続々と輩出してきている。Purine nucleoside phosphorylase (PNP) 欠損は自己免疫疾 患や白血病に関与することから，PNP に対する遷 移状態構造アナローグとして Fodosine（白血病治 療薬，phase II）や BCX-4208（乾癬病治療薬，phase II）が開発されている。 ほかに抗がん剤として期待 されている SF-4, SDD-8, OGT2378 などが臨床治 験中であり，まさしく低分子医薬品候補の宝庫にな りつつある. 最近には Wiley より単行本（Iminosugars: From synthesis to therapeutic applications) が 発刊されている. ${ }^{25)}$

グリコシダーゼ阻害活性としての代表的なイミノ 糖は deoxynojirimycin（DNJ）（1)である。DNJ は 1968 年にイミノ糖として最初に単離された比較的 不安定なノジリマイシンの還元体として見い出され た. ${ }^{26)}$ その後 1976 年に桑属の葉及び根皮から単離

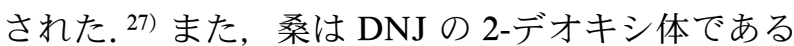
fagomine (2) を産生する. ${ }^{28)}$ DNJ 1 が極めて高い $\alpha-$ グルコシダーゼ活性を有することから一躍注目を浴
び，前述のように DNJ 誘導体の医薬品 Glyset ${ }^{\mathrm{TM}}$ や Zavesca $^{\mathrm{TM}}$ が開発されている。私たちが，イミノ糖 の研究に着手した 1990 年代後半までは D 体が中心 であり L 体の合成及び生物活性研究がほとんどな されていない現状であった。

\section{Fagimine 類の合成と生物活性}

われわれはイミノ糖の立体異性体と生物活性の関 係に興味を持ち，まず不斉炭素の少ない fagomine （2）の全立体異性体の合成から開始した。D体の fagomine（2）及びその異性体 3-epi-fagomine（5）, 3,4-di-epi-fagomine (6) と 4-epi-fagomine (7) は Dセリン由来の Garner アルデヒド $\mathbf{3}$ から誘導される 鍵中間体であるテトラヒドロピリジン 4 を用いて合 成した（Scheme 2). ${ }^{29,30)}$ 4-epi-Fagomine（7）以外は 天然から単離されている。同様に L-セリン由来の Garner アルデヒド ent-3 から 4 種類の L 体 (ent-2, 5-7）を合成した。詳しい合成法は最近筆者の総説 に述べられている. ${ }^{31}$

このようにすべての立体異性体を入手したので各 種グリコシダーゼ阻害活性を検討した結果を Table 1 に示した. ${ }^{32)}$ D-Fagomine (2) は各種 $\alpha$-グルコシ ダーゼに対して阻害活性を有していたが，D-DNJ （1）に比してかなり弱かった。また，D-3-epi-fagomine (5) に弱いながら $\beta$-グルコシダーゼ及び $\beta$-ガ ラクトシダーゼに対して阻害活性がみられたが，そ の他の D 体の fagomine 類には特に注目する阻害活 性はみられなかった。一方，L体に関してはほとん ぞ阻害活性はみられなかったが，ent-5 及び ent-6 に非常に弱いが一部グリコシダーゼに阻害活性が観 測された。 ヒドロキシ基の数及びその立体配置で微 妙に各種グリコシダーゼの阻害活性に影響を与える ことが判明した。 


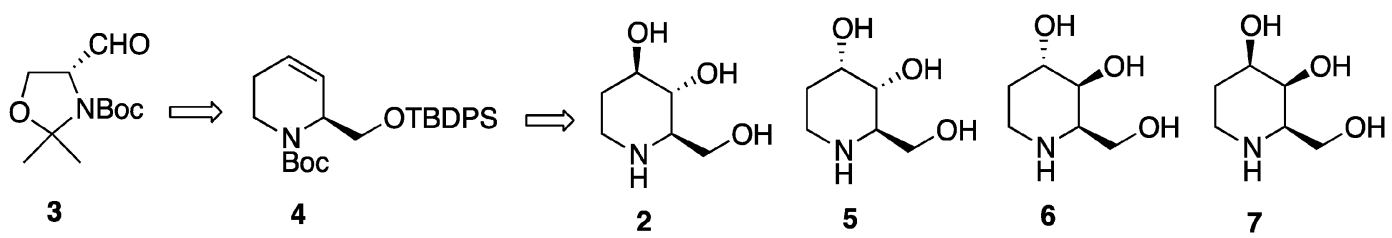

Scheme 2. Synthesis of D-Fagomine and Its Stereoisomers

Table 1. Concentration of D- and L-Fagomine Isomers Giving 50\% Inhibition of Various Glycosidases

\begin{tabular}{|c|c|c|c|c|c|c|c|c|c|c|}
\hline \multirow{3}{*}{ Enzyme } & \multicolumn{10}{|c|}{$\mathrm{IC}_{50}(\mu \mathrm{M})$} \\
\hline & \multicolumn{2}{|c|}{ fagomine 2} & \multicolumn{2}{|c|}{ 3-epi-fagomine 5} & \multicolumn{2}{|c|}{ 3,4-di-epi-fagomine 6} & \multicolumn{2}{|c|}{ 4-epi-fagomine 7} & \multicolumn{2}{|c|}{ 1-deoxynojirimycin $\mathbf{1}$} \\
\hline & $\mathrm{D}$ & $\mathrm{L}$ & $\mathrm{D}$ & $\mathrm{L}$ & $\mathrm{D}$ & $\mathrm{L}$ & $\mathrm{D}$ & $\mathrm{L}$ & $\mathrm{D}$ & $\mathrm{L}$ \\
\hline \multicolumn{11}{|l|}{$\alpha$-glucosidase } \\
\hline rice & 320 & NI & 120 & 188 & NI & 980 & NI & NI & 0.03 & 4.3 \\
\hline rat intestinal maltase & 113 & NI & NI & 357 & NI & 668 & NI & NI & 0.65 & 28 \\
\hline rat intestinal isomaltase & 37 & NI & NI & NI & NI & NI & NI & NI & 0.65 & 150 \\
\hline rat intestinal sucrase & 34 & NI & NI & 225 & NI & NI & NI & NI & 0.51 & 18 \\
\hline \multicolumn{11}{|l|}{$\beta$-glucosidase } \\
\hline almond & $\mathrm{NI}$ & NI & 120 & NI & NI & NI & NI & NI & 80 & 980 \\
\hline rat intestinal cellobiase & $\mathrm{NI}$ & $\mathrm{NI}$ & 39 & 809 & NI & NI & NI & NI & 327 & NI \\
\hline bovine liver & 250 & NI & 5.6 & NI & NI & NI & NI & NI & NI & NI \\
\hline human lysosome & $\mathrm{NI}$ & NI & NI & NI & NI & NI & NI & $\mathrm{NI}$ & NI & NI \\
\hline \multicolumn{11}{|l|}{$\alpha$-galactosidase } \\
\hline coffee beans & $\mathrm{NI}$ & NI & NI & NI & NI & NI & 8.0 & NI & 880 & NI \\
\hline \multicolumn{11}{|l|}{$\beta$-galactosidase } \\
\hline bovine liver & 38 & NI & 3.0 & 960 & NI & NI & NI & NI & NI & 560 \\
\hline rat intestinal lactase & $\mathrm{NI}$ & NI & 4.3 & 122 & NI & NI & NI & NI & 49 & 317 \\
\hline \multicolumn{11}{|l|}{$\alpha$-mannosidase } \\
\hline Jack beans & $\mathrm{NI}$ & NI & NI & NI & NI & NI & NI & NI & NI & NI \\
\hline \multicolumn{11}{|l|}{$\beta$-mannosidase } \\
\hline snail & $\mathrm{NI}$ & NI & NI & NI & NI & NI & NI & NI & NI & NI \\
\hline \multicolumn{11}{|l|}{$\alpha$-L-fucosidase } \\
\hline bovine epididymis & $\mathrm{NI}$ & NI & NI & 260 & NI & NI & NI & NI & NI & NI \\
\hline \multicolumn{11}{|l|}{$\alpha$-L-rhamnosidase } \\
\hline P. decumbens & $\mathrm{NI}$ & NI & NI & NI & NI & NI & NI & NI & NI & NI \\
\hline
\end{tabular}

NI: No inhibition (less than $50 \%$ inhibition at $1000 \mu \mathrm{M}$ ).

\section{DNJ 類の合成と生物活性}

次に，D-DNJ 及びその立体異性体の合成を，同 じく Garner アルデヒド 3 から誘導される 2 種のテ トラヒドロピペリジン体 8 から D-DNJ (1), D-altroDNJ (10), D-allo-DNJ (11), D-manno-DNJ（12)及 び9から D-ido-DNJ (13), D-galacto-DNJ (14), Dgulo-DNJ（15）の合計 7 種類達成した (Scheme 3). 残念ながら，ヒドロキシ基がすべてシス配置の Dtalo-DNJ（16）の合成はできなかった. ${ }^{33,34)}$

同様に L-セリン由来の Garner アルデヒド ent-3 から 7 種類の L 体 (ent-1，10-12，13-15）を合成し た。各種グリコシダーゼ阻害活性を検討した結果を
Table 2, 3 に示したが，D 体，L 体では阻害スペク トルが全く異なることが明らかになつた. ${ }^{35,36)}$

まず, D-DNJ（1）と L-DNJ (ent-1) の rice $\alpha$-グル コシダーゼ阻害活性における Lineweaver-Burk plots を測定したところ，1 は酵素に対して拮抗型 競争的阻害剂 $\left(K_{\mathrm{i}}=5.7 \mu \mathrm{M}\right)$ で，ent-1 は非拮抗型 非競争的阻害剂 $\left(K_{\mathrm{i}}=4.5 \mu \mathrm{M}\right)$ であることがわかつ た。同様に，D-galacto-DNJ (14) と L-galacto-DNJ (ent-14) と coffee bean $\alpha$-galactosidase における Lineweaver-Burk plotsでは，14 は酵素に対して競 争的阻害剂 $\left(K_{\mathrm{i}}=3.5 \mu \mathrm{M}\right)$ で, ent-14は非競争的阻 害剂 $\left(K_{\mathrm{i}}=7.3 \mu \mathrm{M}\right)$ であった。したがって，L体の 


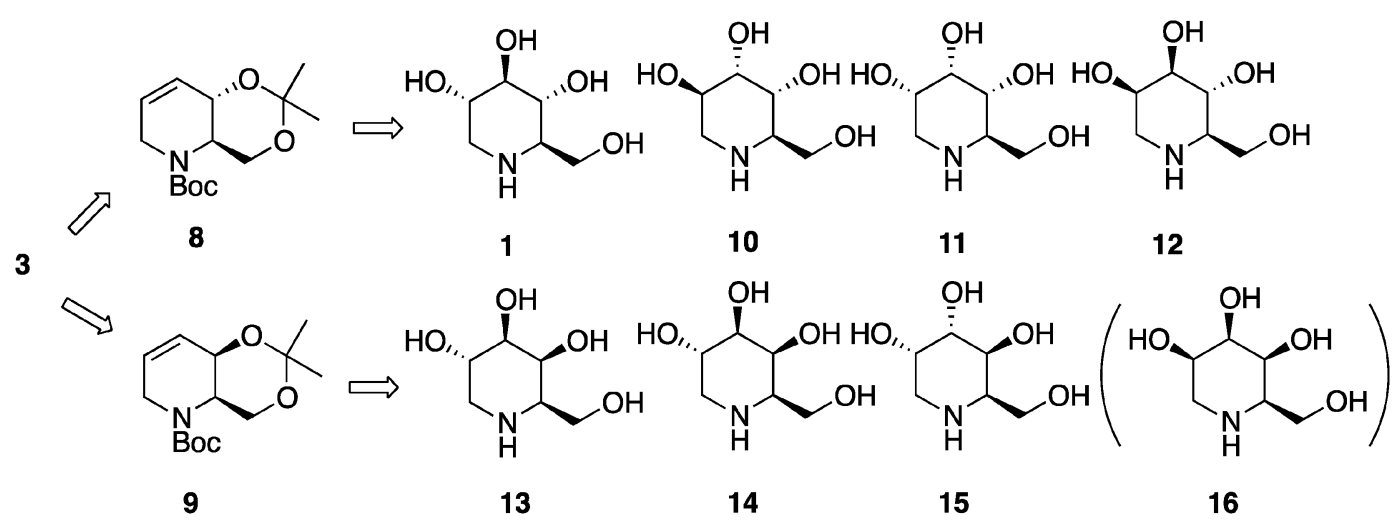

Scheme 3. Synthesis of D-DNJ and Its Stereoisomers

Table 2. Inhibition of Various Glycocidases by D- and L-1-Deoxyazasugers

\begin{tabular}{|c|c|c|c|c|c|c|c|c|c|c|c|c|c|c|}
\hline \multirow{3}{*}{ Enzyme } & \multicolumn{14}{|c|}{$\mathrm{IC}_{50}(\mu \mathrm{M})$} \\
\hline & \multicolumn{2}{|c|}{ DNJ 1} & \multicolumn{2}{|c|}{ manno-DNJ 12} & \multicolumn{2}{|c|}{ allo-DNJ 11} & \multicolumn{2}{|c|}{ altro-DNJ 10} & \multicolumn{2}{|c|}{ galacto-DNJ 14} & \multicolumn{2}{|c|}{ gulo-DNJ 15} & \multicolumn{2}{|c|}{ ido-DNJ 13} \\
\hline & $\mathrm{D}$ & $\mathrm{L}$ & $\mathrm{D}$ & $\mathrm{L}$ & $\mathrm{D}$ & $\mathrm{L}$ & $\mathrm{D}$ & $\mathrm{L}$ & $\mathrm{D}$ & $\mathrm{L}$ & $\mathrm{D}$ & $\mathrm{L}$ & $\mathrm{D}$ & $\mathrm{L}$ \\
\hline \multicolumn{15}{|l|}{$\alpha$-glucosidase } \\
\hline rice & 0.03 & 4.3 & NI & $\mathrm{NI}$ & NI & $\mathrm{NI}$ & $\mathrm{NI}$ & 450 & NI & NI & NI & $\mathrm{NI}$ & NI & $\mathrm{NI}$ \\
\hline rat intestinal maltase & 0.65 & 28 & 110 & NI & NI & $\mathrm{NI}$ & NI & $\mathrm{NI}$ & NI & NI & NI & $\mathrm{NI}$ & NI & NI \\
\hline \multicolumn{15}{|l|}{$\beta$-glucosidase } \\
\hline almond & 80 & 980 & NI & $\mathrm{NI}$ & NI & $\mathrm{NI}$ & $\mathrm{NI}$ & $\mathrm{NI}$ & NI & NI & NI & $\mathrm{NI}$ & 60 & $\mathrm{NI}$ \\
\hline \multicolumn{15}{|l|}{$\alpha$-mannosidase } \\
\hline Jack bean & NI & NI & 840 & $\mathrm{NI}$ & NI & 30 & NI & $\mathrm{NI}$ & NI & NI & NI & $\mathrm{NI}$ & NI & NI \\
\hline rat epididymis & NI & NI & 560 & NI & NI & 59 & NI & $\mathrm{NI}$ & NI & NI & NI & $\mathrm{NI}$ & NI & NI \\
\hline \multicolumn{15}{|l|}{$\beta$-mannosidase } \\
\hline rat epididymis & NI & NI & NI & $\mathrm{NI}$ & NI & $\mathrm{NI}$ & NI & $\mathrm{NI}$ & NI & NI & NI & $\mathrm{NI}$ & NI & $\mathrm{NI}$ \\
\hline \multicolumn{15}{|l|}{$\alpha$-galactosidase } \\
\hline coffee bean & 880 & NI & $\mathrm{NI}$ & $\mathrm{NI}$ & 260 & 290 & NI & $\mathrm{NI}$ & 0.003 & 13 & 160 & NI & 67 & NI \\
\hline Aspergillus niger & NI & NI & NI & $\mathrm{NI}$ & NI & NI & NI & $\mathrm{NI}$ & 1.8 & NI & NI & NI & NI & $\mathrm{NI}$ \\
\hline \multicolumn{15}{|l|}{$\beta$-galactosidase } \\
\hline bovine liver & NI & 560 & NI & NI & NI & $\mathrm{NI}$ & NI & $\mathrm{NI}$ & $\mathrm{NI}$ & 560 & NI & $\mathrm{NI}$ & 850 & $\mathrm{NI}$ \\
\hline rat epididymis & NI & NI & NI & NI & NI & NI & NI & NI & 24 & NI & NI & $\mathrm{NI}$ & NI & NI \\
\hline \multicolumn{15}{|l|}{$\alpha$-1-fucosidase } \\
\hline bovine epididymis & NI & NI & 39 & $\mathrm{NI}$ & NI & $\mathrm{NI}$ & 194 & $\mathrm{NI}$ & $\mathrm{NI}$ & 0.63 & NI & 156 & NI & $\mathrm{NI}$ \\
\hline
\end{tabular}

NI: No inhibition (less than $50 \%$ inhibition at $1000 \mu \mathrm{M}$ ).

Table 3. Inhibition of Human Lysosomal Glycosidases by D- and 1-L-Deoxyazasugars

\begin{tabular}{|c|c|c|c|c|c|c|c|c|c|c|c|c|}
\hline & \multicolumn{12}{|c|}{$\mathrm{IC}_{50}(\mu \mathrm{M})$} \\
\hline & \multicolumn{2}{|c|}{ DNJ 1} & \multicolumn{2}{|c|}{ manno-DNJ 12} & \multicolumn{2}{|c|}{ allo-DNJ 11} & \multicolumn{2}{|c|}{ galacto-DNJ 14} & \multicolumn{2}{|c|}{ gulo-DNJ 15} & \multicolumn{2}{|c|}{ ido-DNJ 13} \\
\hline & $\mathrm{D}$ & $\mathrm{L}$ & $\mathrm{D}$ & $\mathrm{L}$ & $\mathrm{D}$ & $\mathrm{L}$ & $\mathrm{D}$ & $\mathrm{L}$ & $\mathrm{D}$ & $\mathrm{L}$ & $\mathrm{D}$ & $\mathrm{L}$ \\
\hline$\alpha$-glucosidase & 0.04 & NI & NI & NI & NI & NI & NI & NI & NI & NI & NI & $\mathrm{NI}$ \\
\hline$\beta$-glucosidase & 240 & NI & NI & $\mathrm{NI}$ & NI & $\mathrm{NI}$ & NI & NI & $\mathrm{NI}$ & $\mathrm{NI}$ & 66 & $\mathrm{NI}$ \\
\hline$\alpha$-mannosidase & $\mathrm{NI}$ & NI & NI & $\mathrm{NI}$ & NI & 64 & NI & NI & $\mathrm{NI}$ & $\mathrm{NI}$ & NI & $\mathrm{NI}$ \\
\hline$\beta$-mannosidase & $\mathrm{NI}$ & NI & NI & NI & $\mathrm{NI}$ & $\mathrm{NI}$ & $\mathrm{NI}$ & NI & $\mathrm{NI}$ & $\mathrm{NI}$ & NI & $\mathrm{NI}$ \\
\hline$\alpha$-galactosidase & NI & NI & NI & NI & NI & $\mathrm{NI}$ & 0.07 & 45 & 920 & NI & 390 & NI \\
\hline$\beta$-galactosidase & NI & NI & NI & NI & NI & NI & 90 & NI & NI & $\mathrm{NI}$ & NI & NI \\
\hline$\alpha$-fucosidase & $\mathrm{NI}$ & NI & 221 & NI & NI & NI & NI & 3.5 & NI & 150 & NI & NI \\
\hline
\end{tabular}

NI: No inhibition (less than $50 \%$ inhibition at $1000 \mu \mathrm{M}$ ). 


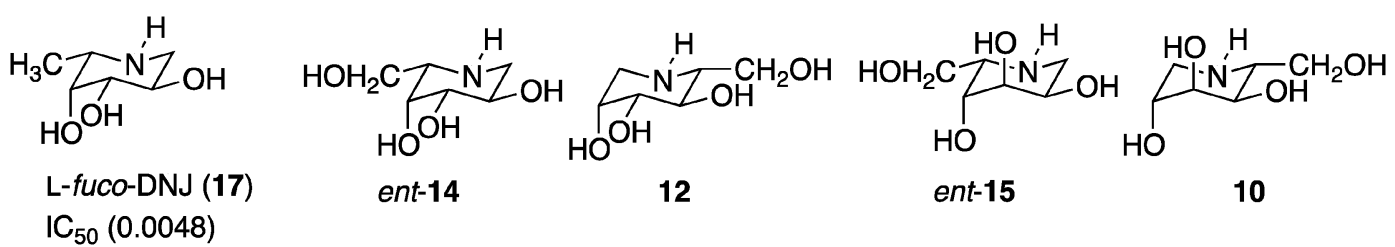

Scheme 4. The Structures of 1-Deoxyfuconojirimycin (DFJ) Analogues and Their $K_{\mathrm{i}}$ Values for Bovine Epididymis R-L-Fucosidase

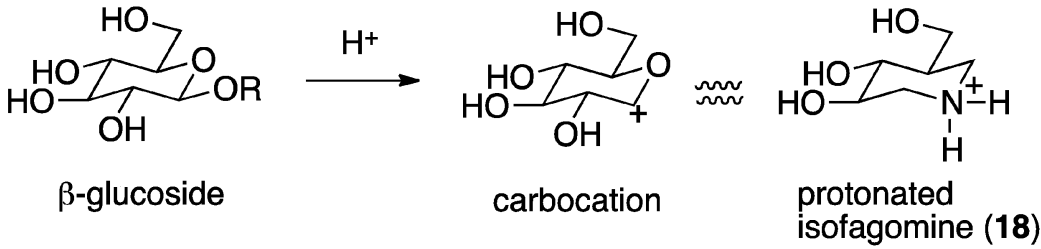

Scheme 5. Hydrolysis of $\beta$-Glucoside

ent-1 や ent-14 が阻害活性を示したのは D 体のよう に基質の構造類似性ではなく結合部位の違いによる 非拮抗型阻害様式を示したものと考えられる. 一方, L- $\alpha$-フコシダーゼに対する阻害活性は D 体におい ては D-manno-DNJ (12) と D-altro-DNJ（10)のみに 阻害活性がみられ，L体では L-galacto-DNJ (ent-14), L-gulo-DNJ（ent-15）のみに阻害活性がみられた.

その中で最も高い阻害活性を示したのは ent-14 であり, 以下 12, ent-15, 10 の順番であった (Scheme 4). 2 位， 3 位及び 5 位の立体配置が活性中心にお ける認識と結合に重要であると考えられる。これら の DNJ 誘導体は L- $\alpha$-フコシダーゼに対する阻害様 式は Lineweaver-Burk plotsにより拮抗的に阻害し ていることがわかったので, D体， L 体にかかわら ず，対象基質の構造相同性が重要であると推察され る. また, 細胞のがん化に伴う細胞表面の糖脂質の 糖鎖構造の変化にフコシル化が重要であると報告さ れている。しかしながら, ent-14 は L-fuco-DNJ (17)に比べて阻害活性がかなり弱いことから 5 位の 疎水性基の重要性が強く示唆された。それゆえ，5 位の疎水性基への化学修飾でより強力な阻害剂創出 の可能性が期待される.

\section{Isofagimine 類の合成と生物活性}

次に, 単糖グルコースのアノマー位が窒素に置換 した 1-アザ糖の isofagomine（18)に強い $\beta$-グリコ シダーゼ阻害活性を有することが Bols によって見 い出された. 37) この強い阻害活性は糖のグリコシド 結合切断の特徵であるカチオン性の遷移状態と構造 が似ているためとされている。すなわち，アノマー

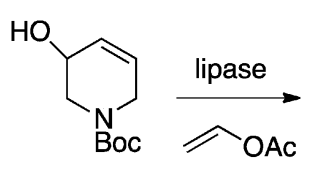<smiles></smiles><smiles>OC1C=CC[18O]C1</smiles>

HO,<smiles>O=C(O)c1ccccc1</smiles>

19

20

(R)-19

(S)-19

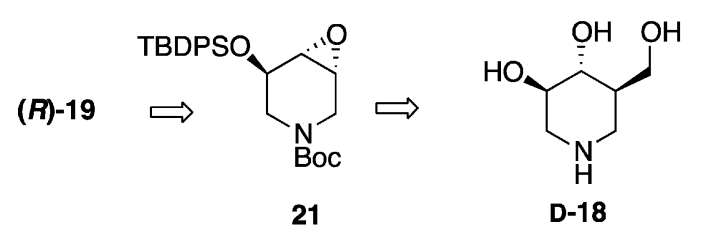

Scheme 6. Synthesis of D-Isofagomine

部のカルボカチオン体に近似していると考えられて いる (Scheme 5).

最初に, 単糖のアノマー位が窒素に置換した 1アザ糖の isofagomine (18)の合成を行つた. 閉環义 タセシス反応を利用して二段階高収率で合成できる 5-ヒドロキシ-3-ピペリデン体 19 に対して固定化リ パーゼを用いる速度論的光学分割法で 19 の両エナ ンチオマーを光学純度よく高収率で得た. このよう にして得たキラル素子 $(R)$-19 からエポキシ体 21 を経て立体選択的に目的のイソファゴミンの合成に 成功した (Scheme 6)。同様にして, $(S)$-19 から L-18 を合成した. ${ }^{38,39)}$ また，18 は，分子内エンイン 反応を用いる方法においても合成された. ${ }^{40,41)}$

次にわれわれは, isofagomine 類のすべての立体 異性体（8 種）の合成を企画し，そのためのキラル 素子として 5-ヒドロキシメチルピペリデン体 22 を 
設定した。両エナンチオマー 19 のヒドロキシル基 スズメチレン基に変換した化合物の [2,3] Still-Wittig 転位で 22 を得た. 22 のオレフィン部に対する 酸化反応でイソファゴミンを含む 4 種の異性体の合 成を行うことができた (Scheme 7). 42)

$$
\text { さらに，それらの }(S) \text {-19からのエナンチオマー }
$$

の合成にも成功したので，各種グリコシダーゼ阻害 作用を行い, 光学異性体間の生物活性評価を行つ た. その結果は Table 4 に示されている. ${ }^{32)}$

予想通り，D-18 は強い $\beta$-グルコシダーゼ阻害活 性を有しており，また，L-18においても弱いなが ら活性がみられた。一方， $\alpha$-グルコシダーゼ阻害活
(R)-19

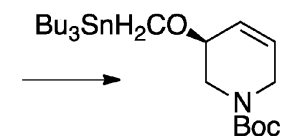

\section{$[2,3]$-Wittig rearrangement}<smiles>C=CCC1CN(C(=O)OC(C)(C)C)CCC1CO</smiles>

22

D-isofagomine isomers<smiles>OC[C@H]1CNC[C@@H](O)[C@@H]1O</smiles>

D-18<smiles>OC[C@H]1CNC[C@@H](O)[C@@H]1O</smiles>

D-23 3-epi-isofagomine<smiles>OC[C@@H]1CNC[C@H](O)[C@H]1O</smiles>

D-24 4-epi-isofagomine<smiles>OC[C@H]1CNCC(O)[C@H]1O</smiles>

D-25 3,4-diepi-isofagomine

Scheme 7. Synthesis of D-Isofagomine and Its Stereoisomers

Table 4. Concentration of D- and L-Isofagomine Isomers Giving 50\% Inhibition of Verious Glycosidases

\begin{tabular}{|c|c|c|c|c|c|c|c|c|}
\hline \multirow{3}{*}{ Enzyme } & \multicolumn{8}{|c|}{$\mathrm{IC}_{50}(\mu \mathrm{M})$} \\
\hline & \multicolumn{2}{|c|}{ Isofagomine $\mathbf{1 8}$} & \multicolumn{2}{|c|}{ 3-epi-isofagomine 23} & \multicolumn{2}{|c|}{ 3,4-di-epi-isofagomine 25} & \multicolumn{2}{|c|}{ 4-epi-isofagomine 24} \\
\hline & $\mathrm{D}$ & $\mathrm{L}$ & $\mathrm{D}$ & $\mathrm{L}$ & $\mathrm{D}$ & $\mathrm{L}$ & $\mathrm{D}$ & $\mathrm{L}$ \\
\hline \multicolumn{9}{|l|}{$\alpha$-glucosidase } \\
\hline rice & NI & NI & NI & NI & NI & $\mathrm{NI}$ & $\mathrm{NI}$ & $\mathrm{NI}$ \\
\hline rat intestinal maltase & 653 & NI & NI & NI & NI & $\mathrm{NI}$ & NI & NI \\
\hline rat intestinal isomaltase & 290 & NI & NI & NI & NI & NI & NI & NI \\
\hline rat intestinal sucrase & 531 & 34 & NI & NI & NI & $\mathrm{NI}$ & NI & NI \\
\hline \multicolumn{9}{|l|}{$\beta$-glucosidase } \\
\hline almond & 0.98 & 236 & 443 & NI & NI & $\mathrm{NI}$ & 3.2 & 983 \\
\hline rat intestinal cellobiase & 0.30 & 110 & 334 & $\mathrm{NI}$ & 912 & $\mathrm{NI}$ & 4.5 & 607 \\
\hline bovine liver & 31 & 611 & $\mathrm{NI}$ & NI & NI & 676 & 63 & NI \\
\hline human lysosome & 0.063 & 8.7 & 113 & NI & NI & NI & 54 & NI \\
\hline \multicolumn{9}{|l|}{$\alpha$-galactosidase } \\
\hline coffee beans & NI & NI & NI & NI & NI & $\mathrm{NI}$ & 144 & 450 \\
\hline \multicolumn{9}{|l|}{$\beta$-galactosidase } \\
\hline bovine liver & 3.6 & 821 & NI & NI & NI & 389 & 21 & NI \\
\hline rat intestinal lactase & 0.12 & 20 & 52 & 469 & 211 & 646 & 0.51 & 90 \\
\hline \multicolumn{9}{|l|}{$\alpha$-mannosidase } \\
\hline Jack beans & NI & NI & NI & NI & NI & $\mathrm{NI}$ & $\mathrm{NI}$ & NI \\
\hline \multicolumn{9}{|l|}{$\beta$-mannosidase } \\
\hline snail & NI & NI & NI & NI & NI & $\mathrm{NI}$ & $\mathrm{NI}$ & $\mathrm{NI}$ \\
\hline \multicolumn{9}{|l|}{$\alpha$-L-fucosidase } \\
\hline bovine epididymis & NI & NI & NI & NI & NI & $\mathrm{NI}$ & $\mathrm{NI}$ & NI \\
\hline \multicolumn{9}{|l|}{$\alpha$-L-rhamnosidase } \\
\hline P. decumbens & NI & NI & NI & NI & NI & NI & NI & NI \\
\hline
\end{tabular}

NI: No inhibition (less than $50 \%$ inhibition at $1000 \mu \mathrm{M})$. 
性においては極めて阻害活性は低かった。しかしな がら rat intestinal sucrase に関しては L-18 の方が D 体よりも阻害活性が強かった。また， $\beta$-galactosidase（rat intesitinal lactase）においては，興味ある ことにD-18 と D-24 が極めて高い阻害活性を有して いた．これらのことから，4 位のヒドロキシ基の立 体配置はこれらの酵素に対する阻害活性に対して爰 密に影響を与えていないことがわかった.

グリコスフィンゴリピド (glycosphingolipid; GSL) の異常蓄積で引き起こすリソソーム蓄積疾病のゴー シェ病は, GSL グルコシルセラミド（glucosylceramide; GluCer）を分解するリソソーム加水分解䤉 素であるリソソーム酵素酸 $\beta$-グルコシダーゼ（グ ルコセレブロシダーゼ ; glucocerebrosidase; GCase) をコードする遺伝子における遺伝子欠損 (突然変異) に起因する，D-Isofagomine は，組換えヒト酸ベー ターグルコシダーゼ（GCase）の強力な阻害剤であ る. Isofagomine 等の酵素阻害剂を使用して, リソ ソーム蓄積疾患における突然変異酵素活性を強化す るための薬理学的シャペロン法は有効であると報告 されている.43) そこで， $\beta$-gulcosidase (human lusosome）に対する isofagomine（D-18）及び異性体 D-23-25 の阻害活性の相関関係を広野らが開発した ブラウン動力学法によるドッキングプログラムで䤉 素ーリガンド複合体構造の解析を行つた. Inducedfit ドッキング法で計算された上位 10 位までのドッ キングモデルを重ね合わせた図を Fig. 1 に示した. Isofagomine（D-18）が立体配座の最も小さいずれ で，以下 $\mathrm{D}-\mathbf{2 4}, \mathbf{2 3}, 25$ の順番でずれが大きくなり, 阻害活性の強さと一致している。一方, 2-pro- pylisofagomine を合成したが， $\beta$-グルコシダーゼ阻 害活性の低下が観測された. ${ }^{44)}$

\section{6. $\alpha$-1-C-Alkyliminofuranose 類の合成と生物活} 性

糖尿病は風邪と同じように万病のもとになるほど 深刻な疾患であり，血中の高血糖状態が継続し，血 中の赤血球や組織のタンパクのグリケーションによ って，網膜症や末梢神経変性などが起こる。慢性化 に伴い動脈硬化症も進行させ，心筇梗塞，脳梗塞， 脳卒中など生命予後に係わる疾病を招く非常に怖い 病気である。糖尿病治療薬として，私たちは小腸粘

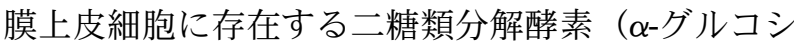
ダーゼ）の作用を競合的に阻害して二糖類から単糖

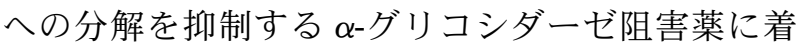
目した。 $\alpha$-グルコシダーゼ阻害薬は，麦芽糖やショ

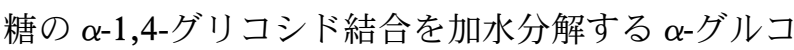
シダーゼのはたらきを抑えることで，グルコースの 消化吸収を緩やかにし，食後の過血糖状態を改善す ることで，インスリン分泌とのタイミングを合わせ ることができる.

現在臨床応用されている食後過血糖改善薬として 第一世代（カルバ糖型）である acarbose, voglibose が知られており，腸管から吸収されないようにデザ インされているので, これら成分の大半は吸収され ずに便中に排泄される。しかし，腸管内での分解産 物の一部が吸収されることが原因ではないかとされ る重篤な肝機能障害, 劇症肝炎の報告がある。一 方，第二世代（イミノ糖型）の miglitol は小腸上部 で吸収されるので低血糖のリスクは少ないが，肝炎 のリスクがあるので肝臓への負担の少ない薬剤が求 (a)

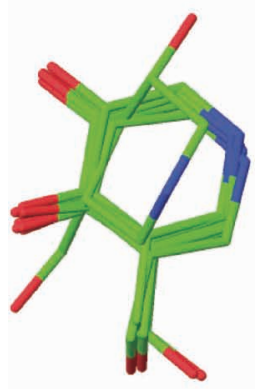

18

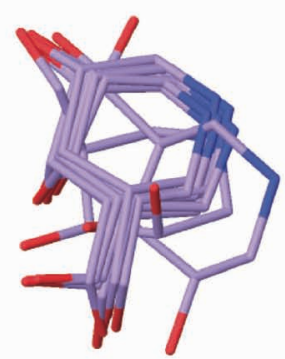

24 (c)

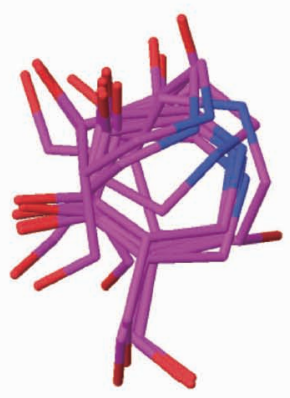

23 (d)

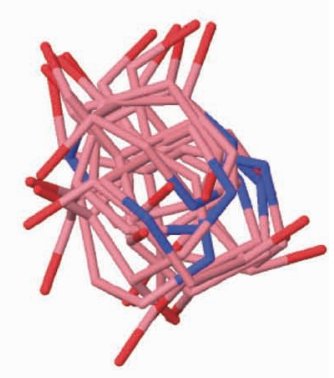

25

Fig. 1. Ligand Poses Extracted from Top 10 Docking Models Ranked by IFDscore (a) D-Isofagomine (18); (b) D-4-epi-Isofagomine (24); (c) D-3-epi-Isofagomine (23); (d) D-3,4-di-epi-Isofagomine (25). 
<smiles>OC[C@H]1C[C@H](CNP)[C@@H](O)[C@H](O)[C@H]1O</smiles>

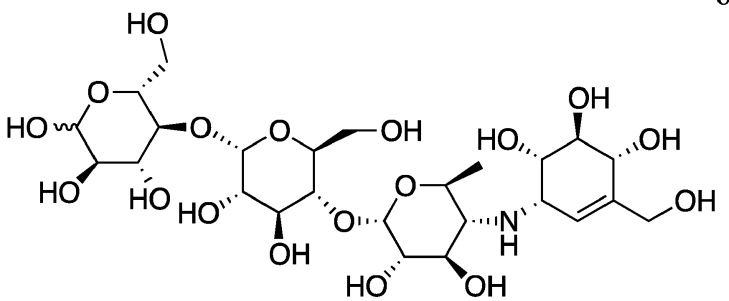

acarbose<smiles>OCC(CO)N[C@H]1C[C@](O)(CO)[C@@H](O)[C@H](O)[C@H]1O</smiles><smiles>OC[C@H]1OC([18OH])[C@@H](O)[C@H](O)[C@H]1O</smiles>

$\alpha$-glucoside<smiles>OCC1NC[C@@H](O)[C@H](O)[C@H]1O</smiles>

D-DNJ<smiles>OCCN1C[C@H](O)C(O)[C@H](O)[C@H]1CO</smiles>

miglitol<smiles>[2H]CC1NC(CO)[C@@H](O)[C@H](O)[C@H]1O</smiles>

$\alpha-1-C$-DNJ

voglibose

Fig. 2. Sugar Mimics and Antidiabetic $\alpha$-Glucosidase Inhibitors<smiles>O=C1OC[C@H]2C=C[C@@H](I)N12</smiles>

D-26

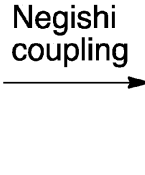

Scheme 8. Synthesis of $\alpha$-1-C-Alkyliminofuranoses<smiles>[R]C[C@H]1C=C[C@@H]2COC(=O)N12</smiles>

D-27<smiles>OCC1N[C@H](CP)[C@@H](O)[C@H]1O</smiles>

D-28

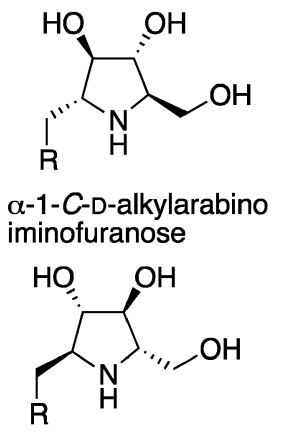

$\alpha-1-C$-L-alkylarabino iminofuranose
められているなどまだいくつかの課題がある現状で ある．構造式からみてみるとカルバ糖はアノマー位 にアミノ置換基を有しており，イミノ糖（miglitol） のアノマー位はデオキシ体でアミノ基に置換基を有 している。しかしながら， $\mathrm{N}$ 位アルキル置換基は 窒素基の速い反転のため立体配座的には安定ではな い，一方，アノマー位アルキル置換基は立体配座は 固定化され，不安定な $N, O$-アセタール基の安定置 換基とみなすこともできる．これまでに，C1 位に アルキル基が置換したイミノピラノース（ピペリジ ン）型のイミノ糖グリコシドミミックとして多く合 成されている。しかしながら，C1 位にアルキル基 が置換したイミノフラノース（ピロリジン）型の合 成は少なく, しかも $\mathrm{L}$ 型糖の研究はほとんどなさ れていない現状であった（Fig. 2).
そこで，C1 位にアルキル基が置換したフラノー ス型イミノ糖の両エナンチオマーの触媒的不斉合成 法の開発を企画した。 Trost が開発した不斉アリル 位アミノ化反応を 2 回用いて合成中間体ビシクロピ ロリジン体 D-26 を入手した。次に，鍵反応の根岸 カップリングでアルキル側鎖を導入後酸化，加水分 解を経て目的の $\alpha$-1-C-alkyl-D-arabinofuranose D-28 を合成した (Scheme 8). 同様に, L-26 から $\alpha-1-C$ alkyl-L-arabinofuranose L-28 の合成に成功した. ${ }^{45)}$

両エナンチオマーを合成したので， $\alpha$-グリコシ ダーゼ阻害活性を行ったところ，意外にもより強い 酵素阻害活性を示すのは D 型ではなく L 型誘導体 であることを見い出した（Table 5).

そこで $\mathrm{C} 1$ 位に種々のアルキル基側鎖の誘導体の ライブラリー構築を行い構造活性相関研究をしたと 
<smiles>[R]C[C@H]1N[C@H](CO)[C@@H](O)[C@H]1O</smiles>
$\alpha-1-C$-alkyl-DAB D-28<smiles>[R]CC1N[C@H](CO)[C@@H](O)[C@@H]1O</smiles>

$\alpha-1-C$-alkyl-LAB L-28<smiles>OC[C@H]1NC[C@@H](O)C1O</smiles>

LAB 29<smiles>CCCCN1C[C@H](O)[C@H](O)[C@H]1CO</smiles>

$N$-n-butyl-LAB 30<smiles>CCCCN1CC(O)C(O)C(O)C1CO</smiles>

N-n-butyl-DNJ 31<smiles>CCC1NC(CO)C(O)C(O)C1O</smiles>

$\alpha-1-C-n$-alkyl-DNJ 32a-c<smiles>CCCCC1[C@H](O)C(O)C(CO)N1CCCC</smiles>

$N-n$-butyl- $\alpha-1-C$-butyl-LAB 33

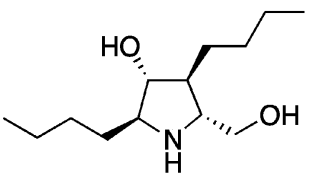

1,3-C-dibutyl-LAB 34

Fig. 3. Alkylated Iminosugars

Table 5. Inhibitory Activities of Intestinal Glucosidases for $\mathbf{1}$ and Concentration of $\mathbf{2 8}$ for Achieving 50\% Inhibition of Rat Intestinal Glycosidases ${ }^{16)}$

\begin{tabular}{cccc}
\hline \hline \multirow{2}{*}{ Substrate } & \multicolumn{3}{c}{$\mathrm{IC}_{50}(\mu \mathrm{M})$} \\
\cline { 2 - 4 } & Maltase $^{a}$ & Isomaltase $^{a}$ & Sucrase $^{a}$ \\
\hline 28c & 0.2 & 4.7 & 0.032 \\
ent-28c & $\mathrm{NI}$ & $\mathrm{NI}$ & 392 \\
$\mathbf{2 8 g}$ & 0.32 & 75 & 0.45 \\
ent-28g & 500 & $\mathrm{NI}$ & 590 \\
\hline
\end{tabular}

${ }^{a}$ From rat intestine. NI: No inhibition (less than 50\% inhibition at 1000 $\mu \mathrm{M})$.

ころ，n-ブチル基を持つ $\mathrm{L}$ 型アラビノイミノフラ ノース誘導体（ $\alpha$-1- $C$-butyl-LAB）は，ラットの小 腸由来の $\alpha$-グリコシダーゼ阻害活性において, 既 存の臨床薬 acarbose, voglibose, miglitol と同等以 上，特にスクラーゼに対しては一桁以上の強力な阻 害活性を示した（Fig. 3 and Table 6).46)

また， $\alpha$-1-C-butyl-LAB 28c は， miglitol とは異 なり, 腹部膨満感や下痢などの副作用発現の原因と なるラクタマーゼ阻害活性を示さなかった. さらに, miglitol の副作用に起因となる肝臟内の糖タンパク 質の糖鎖プロセッシングの阻害活性を HepG2 細胞 で MALDI-TOF 質量分析で解析したところ， 28c は miglitol とは違い細胞表面の糖鎖を改変しない極 めてよい選択的阻害剂であることが判明した。

また， ddy 系雄性マウスを用いた糖負荷試験にお いても本化合物投与群は，陽性対照である miglitol の約 $1 / 10$ 量で食後過血糖を有意に抑制した.

以上の結果から, 本化合物 $\mathbf{2 8 c}$ は, より低濃度で 高血糖を抑えるとともに，副作用発生リスクの少な い次世代型食後過血糖改善薬となり得ると考えられ
Table 6. $\mathrm{IC}_{50}$ Values $(\mu \mathrm{M})$ for $\alpha$-1-C-Alkyl-LAB against Intestinal $\alpha$-Glucosidases, Compared with $\alpha-1-C$-Alkyl-DNJ, Acarbose, Voglivose, and Miglitol

\begin{tabular}{|c|c|c|c|}
\hline \multirow{2}{*}{ Compounds } & \multicolumn{3}{|c|}{$\mathrm{IC}_{50}(\mu \mathrm{M})$} \\
\hline & Maltase & Isomaltase & Sucrase \\
\hline$\alpha-1-C$-Ethyl-LAB (28a) & 2.6 & 11 & 0.68 \\
\hline$\alpha$-1-C-Propyl-LAB (28b) & 1.7 & 47 & 0.26 \\
\hline$\alpha-1-C$-Butyl-LAB (28c) & 0.13 & 4.7 & 0.032 \\
\hline$\alpha-1-C$-Pentyl-LAB (28d) & 0.71 & 18 & 0.19 \\
\hline$\alpha-1-C$-Hexyl-LAB (28e) & 0.51 & 11 & 0.11 \\
\hline$\alpha-1-C$-Heptyl-LAB (28f) & 0.38 & 16 & 0.24 \\
\hline$\alpha$-1-C-Octyl-LAB (28g) & 0.32 & 75 & 0.45 \\
\hline$\alpha$-1-C-Nonyl-LAB (28h) & 0.84 & 171 & 1.4 \\
\hline$\alpha-1-C$-Decyl-LAB (28i) & 1.2 & 606 & 1.7 \\
\hline$\alpha-1-C$-Undecyl-LAB $(\mathbf{2 8 j})$ & 3.9 & NI & 13 \\
\hline $\begin{array}{l}\alpha-1-C \text { - (4-Phenylbutyl) -LAB } \\
(\mathbf{2 8 k})\end{array}$ & 0.22 & 14 & 0.31 \\
\hline $\begin{array}{l}\alpha-1-C \text {-(4-Methylpentyl) -LAB } \\
(\mathbf{2 8 1})\end{array}$ & 0.19 & 12 & 0.24 \\
\hline LAB (29) & 0.93 & 0.36 & 1.0 \\
\hline$N$-butyl-LAB (30) & 63 & 54 & 73 \\
\hline$N$-butyl-DNJ (31) & 2.1 & 2.7 & 58 \\
\hline$\alpha-1-C$-Butyl-DNJ (32a) & 12 & 0.45 & 3.8 \\
\hline$\alpha-1-C$-Hexyl-DNJ (32b) & 4.7 & 0.31 & 2.4 \\
\hline$\alpha-1-C$-Octyl-DNJ (32c) & 2.1 & 0.12 & 1.5 \\
\hline$N$-Butyl- $\alpha-1-C$-butyl-LAB (33) & 25 & NI & 8.8 \\
\hline 1,3-C-Dibutyl-LAB (34) & NI & $\mathrm{NI}$ & $\mathrm{NI}$ \\
\hline Acarbose & 0.18 & NI & 2.9 \\
\hline Voglivose & 0.12 & 5.2 & 0.37 \\
\hline Miglitol & 1.3 & 39 & 1.0 \\
\hline
\end{tabular}

NI: No inhibition (less than $50 \%$ inhibition at $1000 \mu \mathrm{M}$ ).

る.

\section{7. 結論}

生体重要成分ミミック体に的を絞って，化学合成 を武器に創薬科学研究を展開した。特に, これまで 
にほとんど未知であった $\mathrm{L}$ 型イミノ糖の生物機能 研究を実現し, 糖尿病治療薬として極めて有望なグ ルコシダーゼ阻害剤を見い出すことができた。さら に，糖尿病と診断されていない耐糖能異常の糖尿病

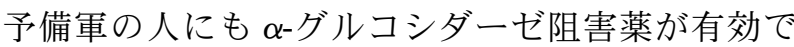
あるという研究が報告されており，今後予防薬の観 点からの新展開も期待される.

様々な生命現象に係わる生体分子の機能を構造的 基盤に基づいて解明することは，現在の有機化学の 重要な課題であり，この分野の発展に貢献すること ができたと考えている.

謝辞本研究の大部分は東北薬科大学薬学部分 子薬教室化学教室で行われたものであり, 教室員及 び数多くの大学院生と学部卒論生の献身的な研究な くしては遂行できませんでした。ここに深く感謝い たします。最後に，これまで私を励まし続けてくだ さった恩師故山崎高應富山医科薬科大学名誉教授に 深く感謝いたします。

\section{REFERENCES}

1) Yoshimura Y., Asami K., Matsui H., Tanaka H., Takahata H., Org. Lett., 8, 6015-6018 (2006).

2) Yoshimura Y., Kuzea T., Ueno M., Komiya F., Haraguchi K., Tanaka H., Kano F., Yamada K., Asami K., Kaneko N., Takahata H., Tetrahedron Lett., 47, 591-594 (2006) .

3) Yoshimura Y., Yamazaki Y., Kawahata M., Yamaguchi K., Takahata H., Tetrahedron Lett., 48, 4519-4522 (2007).

4) Yoshimura Y., Yamazaki Y., Wachi K., Satoh S., Takahata H., Synlett, 111-114 (2007).

5) Yoshimura $Y .$, Ohta M., Imahori T., Imamichi T., Takahata H., Org. Lett., 10, 34493452 (2008).

6) Yoshimura Y., Yamazaki Y., Saito Y, Takahata H., Tetrahedron, 65, 9091-9102 (2009).

7) Yoshimura Y., Asami K., Imamichi T., Kuroda T., Shiraki K., Takahata H., J. Org. Chem., 75, 4161-4171 (2010).

8) Yoshimura Y., Yamazaki Y., Saito Y., Natori Y., Imamichi T., Takahata H., Bioorg. Med. Chem. Lett., 21, 3313-3316 (2011).

9) Yoshimura Y., Kan-no H., Kiran Y. B., Natori Y., Saito Y., Takahata H., Synthesis,
44, 1163-1170 (2012).

10) Yoshimura Y., Takahata H., Yuki Gosei Kagaku Kyokai Shi, 67, 798-808 (2009) .

11) Ouchi H., Saito Y., Yamamoto Y., Takahata H., Org. Lett., 4, 585-587 (2002).

12) Takahata H., Shimizu M., Amino Acids, 24, 267-272 (2003).

13) Kuraishi Y., Iida Y., Zhang H.-W., Uehara S., Nojima H., Murata J., Saiki I., Takahata H., Ouchi H., Biol. Pharm. Bull., 26, 550-552 (2003).

14) Shimizu M., Nemoto H., Kakuda H., Takahata H., Heterocycles, 9, 245-255 (2003).

15) Ouchi H., Kumagai M., Sakurada S., Takahata, H., Heterocycles, 64, 505-514 (2004).

16) Saito Y., Yamaki T., Kohashi F., Watanabe T., Ouchi H., Takahata H., Tetrahedron Lett., 46, 1277-1279 (2005).

17) Saito Y., Ouchi H., Takahata H., Tetrahedron, 62, 11599-11607 (2006).

18) Saito Y., Watanabe T., Takahata H., Tetrahedron Lett., 47, 3099-3102 (2006).

19) Saito Y., Shinkai T., Yoshimura Y., Takahata H., Bioorg. Med. Chem. Lett., 17, 5894-5896 (2007).

20) Saito Y., Ouchi H., Takahata H., Tetrahedron, 64, 11129-11135 (2008).

21) Sasaki A., Serizawa K., Andoh T., Shiraki K., Takahata, H., Kuraishi Y., J. Pharmacol. Sci., 108, 266-273 (2008).

22) Omori Y., Kagaya K., Enomoto R., Sasaki A., Andoh T., Nojima H., Takahata H., Kuraishi Y., J. Pharmacol. Sci., 109, 532-539 (2009).

23) Saito Y., Yoshimura Y., Takahata H., Tetrahedron Lett., 51, 6915-6917 (2010) .

24) Saito Y., Yoshimura Y., Wakamatsu H., Takahata H., Molecules, 18, 1162-1173 (2013) .

25) "Iminosugars - From Synthesis to Therapeutic Applications," eds. by Compain P., Martin O. R., John Wiley \& Sons Ltd., Chichester, 2007, pp. 1-467.

26) Inoue S., Tsuruoka T., Ito T., Niida T., Tetrahedron, 24, 2125-2144 (1968).

27) Yagi M., Kouno T., Aoyagi Y., Murai H., Nippon Nogei Kagaku Kaishi, 50, 571-572 (1976) .

28) Koyama M., Sakamura S., Agric. Biol. 
Chem., 38, 1111-1112 (1974).

29) Banba Y., Abe C., Nemoto H., Kato A., Adachi I., Takahata H., Tetrahedron: Asymmetry, 12, 817-819 (2001).

30) Takahata H., Banba Y., Ouchi H., Nemoto H., Kato A., Adachi I., J. Org. Chem., 68, 3603-3607 (2003).

31) Takahata H., Heterocycles, 85, 1351-1376 (2012).

32) Kato A., Miyauchi S., Kato N., Nash R. J., Yoshimura Y., Nakagome I., Hirono S., Takahata H., Adachi I., Bioorg. Med. Chem., 19, 3558-3568 (2011).

33) Takahata H., Banba Y., Ouchi H., Nemoto H., Org. Lett., 5, 2527-2529 (2003).

34) Takahata H., Banba Y., Sasatani M., Nemoto H., Kato A., Adachi I., Tetrahedron, 60, 8199 -8205 (2004).

35) Kato A., Kato N., Kano E., Adachi I., Ikeda K., Yu L., Okamoto T., Banba Y., Ouchi H., Takahata H., Asano N., J. Med. Chem., 48, 2036-2044 (2005).

36) Asano N., Ikeda K., Yu L., Kato A., Takebayashi K., Adachi I., Kato I., Ouchi H., Takahata H., Feet G. W. J., Tetrahedron: Asymmetry, 16, 223-229 (2005).

37) Jespersen T. M., Dong W., Sierks M. R., Skrydstrup T., Lundt I., Bols M., Angew. Chem. Int. Ed. Engl., 33, 1778-1779 (1994).

38) Ouchi H., Mihara Y., Watanabe H., Takahata
H., Tetrahedron Lett., 45, 7053-7056 (2004) .

39) Ouchi H., Mihara Y., Takahata H., J. Org. Chem., 70, 5207-5214 (2005).

40) Imahori T., Ojima H., Tateyama H., Mihara Y., Takahata H., Tetrahedron Lett., 49, 265268 (2008).

41) Imahori T., Ojima H., Yoshimura Y., Takahata H., Chem. Eur. J., 14, 10762-10771 (2008).

42) Mihara Y., Ojima H., Imahori T., Yoshimura Y., Ouchi H., Takahata H., Heterocycles, 72, 633-645 (2007).

43) Lieberman R. L., Wustman B. A., Huertas P., Powe A. C. Jr., Pine C. W., Khanna R., Schlossmacher M. G., Ringe D., Petsko G. A., Nat. Chem. Biol., 3, 101-107 (2007) .

44) Taguchi T., Imahori T., Yoshimura Y., Kato A., Adachi I., Kawahata M., Yamaguchi K., Takahata H., Heterocycles, 84, 929-944 (2012).

45) Natori Y., Imahori T., Murakami K., Yoshimura Y., Nakagawa S., Kato A., Adachi I., Takahata H., Bioorg. Med. Chem. Lett., 21, 738-741 (2011).

46) Kato A., Hayashi E., Miyauchi S., Adachi I., Imahori T., Natori Y., Yoshimura Y., Nash R. J., Shimaoka H., Nakagome I., Koseki J., Hirono S., Takahata H., J. Med. Chem., 55, 10347-10362 (2012). 